\title{
新局所麻酔荗 Citanest（L-67）の臨床使用成樍について
}

\author{
茂田貫一*.中西 貫*.阔 伸 光* \\ 中田 実*. 山田孝良*.後藤和光* \\ 日比正也*・沢非孝雄* . 中島英一* \\ 田川清*・福井勝男*・立松惩䘽* \\ 大竹和 行*
}

口腔外科領域の各種小手術は，その大部分が局所浸潤 麻酔および伝達麻酔により行なわれている。1905 年 Einhorn'1) により Procain が合成されて, 長期にわたり 局所麻酡の目的に使用されたが，Procainよりすぐれた 薬㘊を合成しようとする目的で Monocain, Unacain, Carbocain, Xylocain なぞ多くの薬剂が発表されXylocain はその麻酔作用および渗透性の強力なことにより 近洔最も多く使用されるに至つた. 今回麻醉力がXylocai. . と同一で，短時間に麻醉効果が発現し，毒性は $60 \%$ といわれるCitanest の臨床応用を依頼されたので，主 としてロ腔外科領域の患者に使用した成績を報告する。

\section{使用薬 滖}

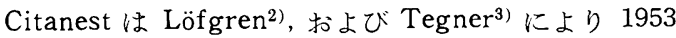
年に合成され，化学的にはXylocain の近縁物質でその 構造式は次のとおりである.

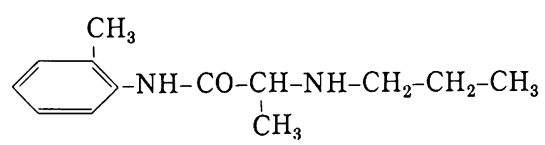

また薬理学的性犋は Åström ${ }^{4}$, Persson ${ }^{5)}$ ，らにより 報告が行なわれており，麻醉力が強大であり，毒性，刺 激性の低いことがあげられている。

われわれが使用したのは雬科用 Citanest で，アドレ ナリンを $1: 300,000$ 含有する Citanest の $3 \%$ 溶液, アドレナリンを $1 ： 200,000$ 含有する Citanest $2 \%$ 溶 液およびアドレナリンを含有しない Citanest $4 \%$ 溶液 の 3 種である。

\section{実験対象および方法}

\section{1) 対 象}

臨床実験は昭和 38 年 6 月 15 日より 8 月 25 日まで

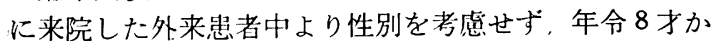
ら 89 才の男 123 名, 女 161 名について, 主として抜 歯および小手術, 抜髄, 曧洞形成などの適応する症例 320 例に Citanest を用いた。

2) 方 法

* 岐皁县立医科大学口堙外科学教室（主任 茂田貫一教授）
Citanest は専用の注射器とカートリッヂ, および普通 歯科用注射器にバイアル容器より適当量を吸引して, 局 所浸潤麻酔あるいは局所浸潤麻酔之伝達麻酔の併用使用 を行ない，伝達麻酔を行なつたものには口唇麻痺発現時 間を測定した。浸潤麻酔にはアドレナリン $1 ： 200,000$ 含有 Citanest $2 \%$ 溶液，アドレナリン $1: 300,000$ 含 有 $3 \%$ Citanest 溶液,アドレナリンを含有しないCitanest $4 \%$ 溶淮の 3 種頪を用い，伝達麻酔にはアドレナリ ンを含有しない $4 \%$ 溶液は使用しなかつた。

成績の記入は藤沢薬品 K K より提供せられた，所定の 用紙の所定の閜に出来るだけ正確，詳細に記入して，集 計した.

\section{1）麻酔発現時間}

\section{臨 床 成 績}

麻酔発現時間は浸潤麻酔の場合は $2 \% ， 3 \% ， 4 \%$ 、 ずれも 1 分以内が最も多く, ついで 2 分以内, 3 分以内 の順で， $2 \%$ の平均麻酙発現時問は 31 秒， $3 \%$ では 55.1 秒， $4 \%$ では 43.6 秒で, $2 \%$ が最も早く, $3 \%$ が最も遅い，男女別では女子がやや発現時間が遅い，伝 達麻酔併用では活とんど $3 \%$ を使用したが，口唇麻疩の 発現に至る時間は，48例中 4 分以上は 14 例で最も多く， ついで 3 分以内 12 例で, 他は 1 分以内, 2 分以内, 4 分以内がほぼ同数であつた．男女別では有意の差は認め られなかつた。（表1参照）

\section{2）麻酔持続時間}

麻酔持続時間は浸潤麻酔の場合は $2 \% ， 3 \% ， 4 \%$ 、 ずれも 30 分以内および 60 分以内が最も多く, 平均持 続時間は $2 \% ， 3 \%$ とに約 68 分で大差がなく，4\% は 44 分でやや短い。伝達麻酔併用では $3 \% 48$ 例中 120 分以上が 19 例, 120 分以内が 14 例, 30 分以内が 7 例, 60 分以内が 6 例で平均持続時間は 117.4 分で, 男女別によ万差はほとんど認められない（表 2 参照）

\section{3）注射液使用量と麻酔発現時間およひ持続時間}

扳歯の際浸潤麻酔を行つたものについては， $2 \% ， 3$ $\% ， 4 \%$ とも $2.0 \mathrm{cc}$ 使用のものが最も例数が多いが， 発現時間は $2 \%$ で平均 30.5 秒， $3 \%$ で 73.6 秒， $4 \%$ で 41.3 秒で $2 \%$ が最も早く $3 \%$ が最も逮い. $3 \%$ で 
表 1. 麻酶発現時問

\begin{tabular}{|c|c|c|c|c|c|c|c|c|c|c|}
\hline 醋 & $\begin{array}{r}\text { Citar } \\
\text { 浀度 } \\
\text { Adrer }\end{array}$ & 性别 & 件数 & $\begin{array}{c}0 \text { 分 } \\
1 \text { 分 } \\
\text { 以内 }\end{array}$ & $\begin{array}{l}1 \text { 分 } \\
2 \text { 分 } \\
\text { 以内 }\end{array}$ & $\begin{array}{l}2 \text { 分 } \\
\text { 3 分 } \\
\text { 以内 }\end{array}$ & $\begin{array}{l}3 \text { 分 } \\
4 \text { 分 } \\
\text { 以内 }\end{array}$ & $\begin{array}{l}4 \text { 分 } \\
\text { 以上 } \\
2\end{array}$ & $\mid \begin{array}{l}\text { 不な } \\
\text { 明し } \\
\text { 記念 } \\
\text { 入恶 }\end{array}$ & 平均 \\
\hline \multirow{9}{*}{$\begin{array}{l}\text { 浸 } \\
\text { 潤 } \\
\text { 麻 }\end{array}$} & & 男 & 23 & 19 & 1 & 3 & 0 & 0 & 0 & 25.4 \\
\hline & & 女 & 23 & 16 & 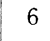 & 1 & 0 & 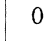 & 0 & 36.5 \\
\hline & 20 & iit & 46 & 35 & 7 & 4 & 0 & 0 & 0 & 31 \\
\hline & 3 & 男 & 23 & 41 & 19 & 8 & 2 & 0 & 3 & 51.4 \\
\hline & & 女 & 106 & 47 & 27 & 25 & 3 & 1 & 3 & 58.8 \\
\hline & $\begin{array}{l}\text { Ad. } \\
1: 300\end{array}$ & 計 & 179 & 88 & 46 & 33 & 5 & 1 & 6 & 55.1 \\
\hline & & 男 & 22 & 15 & 5 & 2 & 0 & 0 & 0 & 42.7 \\
\hline & & 女 & 24 & 16 & 5 & 1 & 0 & 0 & 2 & 44.5 \\
\hline & Ad. & 唁 & 46 & 31 & 10 & 3 & 0 & 0 & 2 & 43. 6 \\
\hline \multirow{6}{*}{$\begin{array}{l}\text { 伝 } \\
\text { 澾 } \\
\text { 纸 }\end{array}$} & $2 \%$ & F & 0 & 0 & 0 & 0 & 0 & 0 & 0 & 0 \\
\hline & & 女 & 1 & 0 & 1 & 0 & 0 & 0 & 0 & 1. 30 \\
\hline & $\begin{array}{l}\text { Ad. } \\
1: 200 \\
\end{array}$ & 部 & 1 & 0 & 1 & 0 & 0 & 0 & 0 & 1. 30 \\
\hline & $3 \%$ & 力 & 19 & ${ }^{2}$ & 2 & 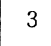 & 7 & 6 & 0 & 2.48 \\
\hline & & 女 & 29 & 4 & 5 & 9 & 2 & 8 & 1 & 2. 27 \\
\hline & $\begin{array}{l}\text { Ad: } \\
1: 300\end{array}$ & 計 & 48 & 8 & 7 & 12 & 6 & 14 & 1 & 2. 37 \\
\hline \multirow[t]{3}{*}{ 䣷 } & $4 \%$ & נJ & . & 0 & 0 & 0 & 0 & 0 & 0 & 0 \\
\hline & & 女 & 0 & 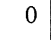 & 0 & 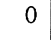 & 0 & 0 & 0 & 0 \\
\hline & 马 & 柿 & 0 & 0 & 0 & 0 & 0 & 0 & 0 & 0 \\
\hline
\end{tabular}

表 2. 暦酹持繶時間

\begin{tabular}{|c|c|c|c|c|c|c|c|c|c|c|}
\hline 醇 & $\begin{array}{c}\text { Citanest } \\
\text { の濃度および } \\
\text { Addrenalin }\end{array}$ & 特 & 件数 & $\begin{array}{l}15 \text { 分 } \\
2 \\
30 \text { 分 } \\
\end{array}$ & 60 & 2' & 120 & $\begin{array}{c}120 \\
\text { 分 }\end{array}$ & 不旫 & 平均 \\
\hline \multirow{5}{*}{ 涅 } & 25 & 男 & 23 & 6 & 7 & 1 & 2 & 2 & 5 & \begin{tabular}{|l} 
分 秒 \\
80.8
\end{tabular} \\
\hline & & 矢 & 23 & 6 & 8 & 2 & 1 & 0 & 6 & 55.7 \\
\hline & $\angle 0$ & it & 46 & 12 & 15 & 3 & 3 & 2 & 11 & 68.3 \\
\hline & $3 \%$ & 男 & 73 & 26 & 15 & 5 & 6 & 9 & 12 & 74.2 \\
\hline & & 女 & 106 & 24 & 35 & 13 & 9 & 10 & 15 & 64 \\
\hline & $\begin{array}{l}\text { Ad. } \\
1: 300,0\end{array}$ & 計 & 179 & 50 & 50 & 18 & 15 & 19 & 27 & 8.1 \\
\hline \multirow[t]{3}{*}{ 酷 } & 4 & 男 & 22 & 11 & 3 & 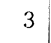 & 0 & 1 & 4 & 35.5 \\
\hline & & 女 & 24 & 9 & 6 & 1 & 1 & 3 & 4 & 53. 2 \\
\hline & Ad. & 計 & 46 & 20 & 9 & 4 & 1 & 4 & 8 & 44.4 \\
\hline \multirow{5}{*}{ 伝 } & & & & 0 & 0 & 0 & 0 & & 0 & 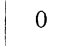 \\
\hline & & 大 & 1 & 0 & 0 & 0 & 0 & 1 & 0 & 180 \\
\hline & $\begin{array}{l}\text { Ad. } \\
1: 200,\end{array}$ & it & 1 & 0 & 0 & 0 & 0 & 1 & 0 & 180 \\
\hline & $3 \%$ & 男 & 19 & 3 & 3 & 0 & 7 & 6 & 0 & 112.5 \\
\hline & & 火 & 29 & 4 & 3 & 1 & 7 & 13 & 1 & 122.3 \\
\hline 乘 & $\begin{array}{l}\text { Ad. } \\
1: 200,000\end{array}$ & it & 48 & 7 & 6 & 1 & 14 & 19 & 1 & 117.4 \\
\hline \multirow[t]{3}{*}{ 莋 } & $4 \%$ & . & 0 & 0 & 0 & 0 & 0 & 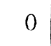 & 0 & 0 \\
\hline & & 力 & 0 & 0 & 0 & 0 & 0 & 0 & 0 & 0 \\
\hline & 念有せず & 計 & 0 & 0 & 0 & 0 & 0 & 0 & 0 & 0 \\
\hline
\end{tabular}

$1.0 \mathrm{cc}$ 使用した 39 例と, $2.0 \mathrm{cc}$ 使用 86 例を比炨与 ると，1.0 cc 使用したものは平均発现㭙閌 46.8 秒で， $2.0 \mathrm{cc}$ 使用の 73.6 秒上りも早い. $4 \%$ では $1.0 \mathrm{cc}$ 使 今のものも，1.5 cc 使用のものも， $2.0 \mathrm{cc}$ 使用のもの
もいずれも大差がない，持続時閒については $2 \% 2.0 \mathrm{cc}$ 使用のものは 63.3 分, $3 \% 2.0 \mathrm{cc}$ 使用のものは 80.3 分, $4 \% 2.0 \mathrm{cc}$ 使用のものは 49.8 分で, $2 \%$ が最も 早く, $3 \%$ が最も遅い，わずか 8 例ではあるが $3 \% 3.0$ cc 使用したものが発現時間 38.8 秒できわめて早く, 持続時間も 104.3 分で比幁的長い $4 \%$ は注射液の使 用量にかかわらず持続時間は 60 分内外で比校的短い。 (表 3 参照)

抜歯に伝垟麻酥併用を行なつたものはほ上んど $3 \%$ の 必使用したが，口唇麻痻発琴時間は $2.5 \mathrm{cc}$ 使用のもの が平均 330 秒で最も遅く, ついで $4.0 \mathrm{cc}$ 使用の 202.4 秒, $3.0 \mathrm{cc}$ が 166.6 秒, $2.0 \mathrm{cc}$ が 84 秒, $1.5 \mathrm{cc}$ が 75 秒で最も早い, $4.5 \mathrm{cc}$ 使用は 1 例のみで 300 秒であつ た. (表 4 参照)

手術に浸潤麻酔を行なつたものは $3 \%$ のみ使用したが、 $3.0 \mathrm{cc}$ が平均発現㭙間 11.7 秒で最も早く, 次は $5.0 \mathrm{cc}$ が 35 秒, $1.0 \mathrm{cc}$ が 37.5 秒, $2.0 \mathrm{cc}$ が 48.3 秒, $4.0 \mathrm{cc}$ が 87.5 秒で最も痋い。持続時間は $5.0 \mathrm{cc}$ が 27.5 分 で最も短かく, $1.0 \mathrm{cc}$ が 63.3 分で最も長く, $3.0 \mathrm{cc}$ と $4.0 \mathrm{cc}$ はいずれも約 40 分で大差がない（表 5 参照）

手術に伝達麻酥作用したものは $5.0 \mathrm{cc}$ 使用の 5 例を 除いて, 他は各 1 例のみで此炨を行ない難いが, $5.0 \mathrm{cc}$ 使用の 5 例について観察与ると口唇麻瘦発現時間 4 分以 上が 3 例, 2 分以内之 3 分以内が各 1 例で平均 216 秒, 持続时間は 30 分以内 3 例, 60 分以内, 120 分以上が各 1 例で平均 42.8 分であつた。（表 5 参照）

保存処置にはいつれも $3 \%$ の浸润麻酷を行なつたが, 発現時間は $2.0 \mathrm{cc}$ 俅用のものが平均 46.7 秒で $1.5 \mathrm{cc}$ 使用の 60 秒よりもやや早く,持続時間は 55 分と 65 分 で大差がない（表 5 参照）

\section{4）症例別平均麻酔発現時間および持続時間}

抜歯については表 6 に示与とおり集計上の“ばらつき” が多く比惔に困難であるが発琴時間は最大 260 秒から最 小 10 秒まであり，持続㫾間は最大 180 分で，最小 15 分であつた。（裴6 参照）

手術については歯慒骨吸収不全に刘与る歯慒骨整形手 術 7 例, $\mathrm{P}_{2} \sim \mathrm{P}_{3}$ の瞥肉并切除手術 5 例, 歯根装胞の根 端切除手術の 4 例を除いて各 1 例づつであるが，発現時 間はこの 3 症例中栜慒骨整形手術を行なつたものの平均 51.5 秒が最も早く, ついで根端切除の 70 秒で, 歯肉 升切除手術を行なつたものの 88 秒が㘿も逯い, 平均持 続時間は歯槽骨整形の78 分が最も長く,ついで歯肉升切 除の 45 分で, 根端し除は 35 分で最も短い。（表 7 参 照)

保存の症例別では抜蹎に際して浸澗麻酔を行なつた 4 例之, 窝洞形成時の 1 例であるが, 発現時閒は40〜60秒， 持続時間は 50〜70 分であつた。（表 8 参照）

\section{5）部位別平均発現時間および持続時間}

部位別に睍ると $2 \%$ では発現時間は，上顝前㴹 1 歯と 


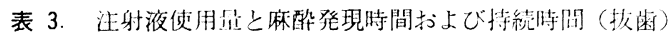

\begin{tabular}{|c|c|c|c|c|c|c|c|c|c|c|c|c|c|c|c|c|c|}
\hline & $\begin{array}{l}\text { チ多不ス卜 } \\
\text { の洎度扰上 }\end{array}$ & & & & & 発 & 现 & 間 & & & & & 持 & 絖 & 時 & 胴 & \\
\hline & $\begin{array}{l}\text { びアドレナ } \\
\text { リンの有無 }\end{array}$ & 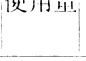 & IT效 & $\begin{array}{l}0 \sim 1 \\
\text { 分以内 }\end{array}$ & $\begin{array}{l}1 \sim 2 \\
\text { 分以内 }\end{array}$ & $\begin{array}{l}2 \sim 3 \\
\text { 分以内 }\end{array}$ & $\begin{array}{l}3 \sim 4 \\
\text { 分以内 }\end{array}$ & 4 以上 & 不明 & 平均 & $\begin{array}{l}15 \sim 3 \\
\text { 分以队 }\end{array}$ & $\begin{array}{l}30 \sim 60 \\
\text { 分以队 }\end{array}$ & $\begin{array}{l}60 \sim 90 \\
9 \text { 分以内 }\end{array}$ & $90 \sim$ & 20 以上 & 不明 & 平均 \\
\hline & & $1.0 \mathrm{cc}$ & 3 & 2 & & 1 & & & & 55 秒 & & 2 & 1 & & & & 56.7 分 \\
\hline & & $1.5 "$ & 7 & 7 & & & & & & $25 "$ & 2 & 3 & & 1 & & 1 & 42.5 \\
\hline & & $2.0 "$ & 33 & 24 & 7 & 2 & & & & $30.5 "$ & 1 & 13 & 7 & 1 & 2 & 9 & 63.3 \\
\hline & & $2.5 "$ & 1 & & & & & & & $60 "$ & & & & & 1 & & 120 \\
\hline & $2 \%$ & $3.0=$ & 1 & 1 & 1 & & & & & $10 "$ & & 1 & & & & & 50 \\
\hline & & $3.5=$ & & & & & & & & & & & & & & & \\
\hline & & $4.0 "$ & 1 & & & 1 & & & & $120 "$ & & & & & 1 & & 120 \\
\hline & Ad. & $4.5 "$ & & & & & & & & & & & & & & & \\
\hline & $1: 200,000$ & $5.0 "$ & & & & & & & & & & & & & & & \\
\hline & & $1.0 \mathrm{cc}$ & 39 & 24 & 6 & 6 & 3 & & & 46.8 秒 & 6 & 10 & 9 & 2 & 4 & 8 & 60.7 秒 \\
\hline 浸 & & $1.5 "$ & 15 & 11 & 2 & 2 & & & & $44.1 "$ & 3 & 5 & 3 & 1 & 2 & 1 & 55 " \\
\hline & & $2.7 "$ & 86 & 33 & 25 & 21 & 1 & 4 & 2 & $73.6 "$ & 10 & 24 & 18 & 3 & 18 & 13 & $80.3 "$ \\
\hline 閵 & & $2.5 "$ & 1 & & 1 & & & & & $90 "$ & & 1 & & & & & $45 "$ \\
\hline & $3 \%$ & $3.0=$ & 8 & 5 & 3 & & & & & $38.8 "$ & 2 & 1 & 1 & & 3 & 1 & $104.3 "$ \\
\hline 麻 & & $3.5 "$ & & & & & & & & & & & & & & & \\
\hline & & $4.0 "$ & 2 & & 2 & & & & & $60 "$ & & & & 2 & & & $90 "$ \\
\hline $\mathrm{PH}_{\mathrm{r}}^{\mathrm{L}}$ & Ad. & $4.5 "$ & & & & & & & & & & & & & & & \\
\hline & $1: 300,000$ & $5.0 "$ & 1 & & & 1 & & & & $120 "$ & & & 1 & & & & $60 "$ \\
\hline & & $1.0 \mathrm{cc}$ & 7 & 6 & 1 & & & & & 32. 1秒 & 2 & & 2 & 1 & 1 & 1 & 61.7 分 \\
\hline & & $1.5 \%$ & 12 & 8 & 4 & & & & & $40 "$ & 4 & 2 & 1 & & 2 & 3 & $76.1 "$ \\
\hline & & $2.0 "$ & 24 & 17 & 3 & 3 & & & 1 & $41.3 "$ & 12 & 3 & 2 & 2 & 1 & 4 & $49.8 "$ \\
\hline & & $2.5 "$ & & & & & & & & & & & & & & & \\
\hline & $4 \%$ & $3.0 "$ & 3 & & 2 & & & & 1 & $60 "$ & 1 & 1 & & & 1 & & $60 "$ \\
\hline & & $3.5 "$ & & & & & & & & & & & & & & & \\
\hline & & $4.0 "$ & & & & & & & & & & & & & & & \\
\hline & & $4.5 \%$ & & & & & & & & & & & & & & & \\
\hline & & $5.0 "$ & & & & & & & & & & & & & & & 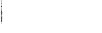 \\
\hline
\end{tabular}

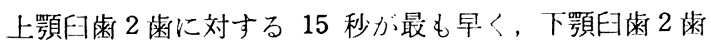
に対する 120 秒が最も遅い，持続時間は下䫇智歯に対す る 108.8 分が最も長く，上靧田齿 2 歯に対する 38.3 分

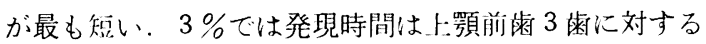
20 秒が最も早く, 下箩智歯に対する 147.2 秒が最も遅 い，持続時間は下顎智歯に対する 129.2 分が最も長く, 上顎目歯 4 歯に対寸る 20 分が最も短い. $4 \%$ では発現

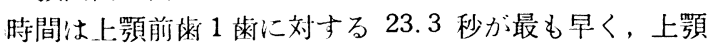
前歯 3 歯に対する 60 秒が最》革い、持続時間は下顎智 歯に対する 133.8分が最も長く, 下䫟前歯 1 歯に対する 10 分が最も短か心（表 $9 ， 10 ， 11$ 参照)

\section{6) 拡 散 力}

浸潤麻酔では抬散つは $2 \%$ で（十）93.4\%，(H) 6.52 $\%, 3 \%$ (+) $92.1 \%$, (H) $3.35 \%, 4 \%$ では (+) $95.6 \%$ といつれも $100 \%$ 近い㕬散力を示し，(土）は 3 \%にわずか. $2.78 \%$ 認められたに過ぎない。

伝逹麻䣷では $3 \%$ では(土)0，(+)87.5\%，(H)12.5\% で，2\%は1例のみであつたが（+）を示した。
（表 12 参照）

\section{7）術中および術後の観察}

吸引時出!血は浸潤麻酔の $2 \%, 3 \% ， 4 \%$, 其に1〜 2 例の不明を除いて全例に出血は認められなかつた。

手術時出血は浸潤麻酔の $4 \%$ では 46 例中 18 例， $39.1 \%$ に中等度, 7 例， $17.3 \%$ に多量の出血を認めたが， $2 \%$ では中等度 $32.6 \%$, 多量 $2.1 \%$, 3\% では中等度 $33.5 \%$, 多量 $6.1 \%$ の出血で $4 \%$ 上りもやや少い. 伝 達麻酔併用の $3 \%$ では中等度 $43.7 \%$, 多量 $0.8 \%$ の出血 を惉めた。

後疼痛は全症例 320 例中 50 例に軽度の後疼狱と不明 69 例を認めた。

創傷治癒では治癒後の観察が出来ないため記入もれの 患者が多いが， $4 \%$ 浸潤麻酔 1 例之 $3 \%$ 伝達麻酔の 1 例 の不良を除いて約半数は良好であつた。

麻酔效果の判定は手術中の疼捎の有無による臨床的観 察であるが, 疼痛を訴えた 18 例と不明の 7 例を除いて 92.1\% に確実な効果が㴓められた。（表 13 参照） 
表 4. 注射液使用是と麻䣷発現時間および持続時間（抜幽）

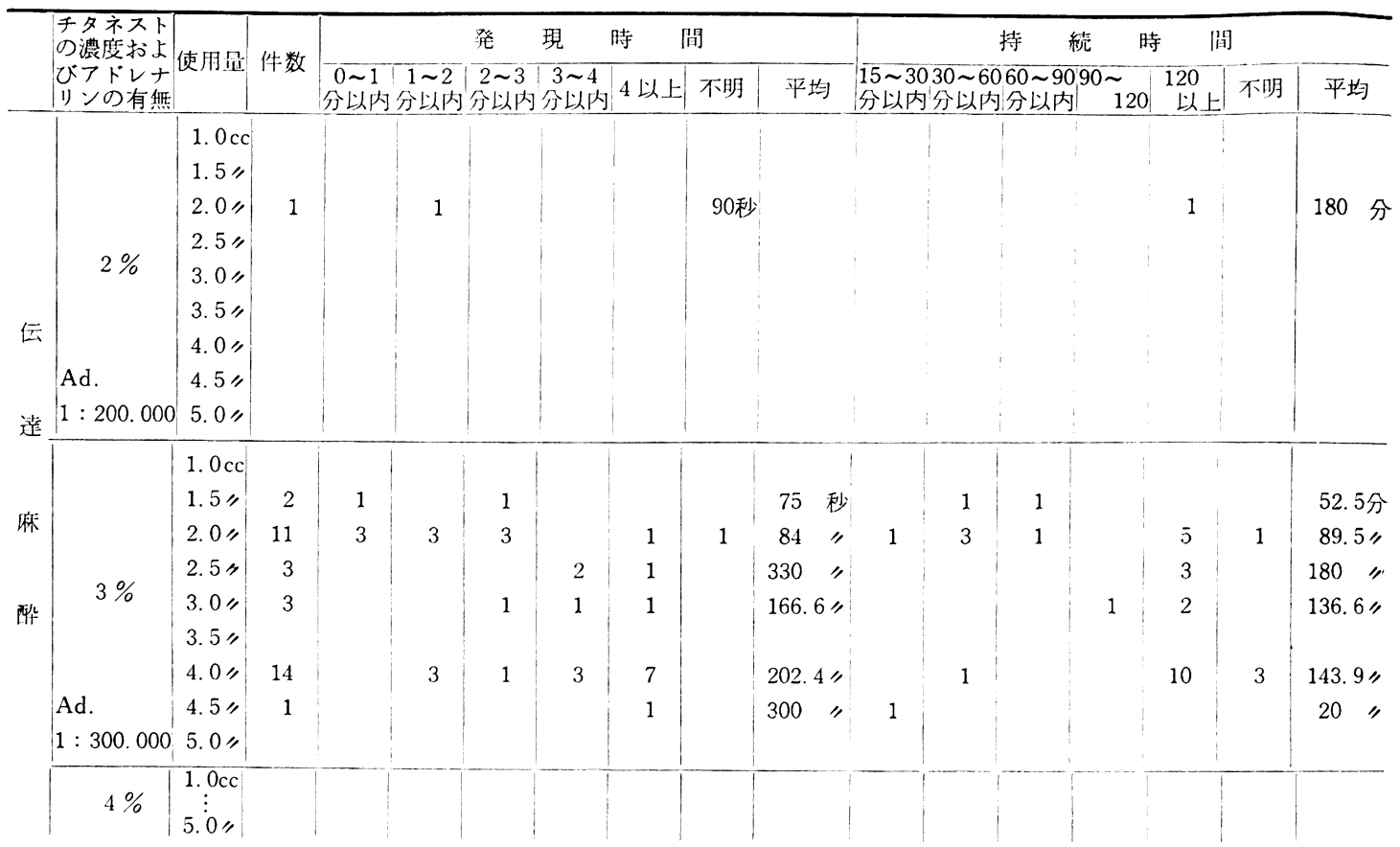

\section{8）副作用}

320 例中頭痛 14 例, 径血 4 例，熱感，発熱 3 例，頭 部ふらつき 1 例, 悪心 1 例, 食欲不振 1 例, 挝全 1 例, 倊意感 1 例, 屃こり 1 例, 計 27 例の埾微な副作用を認 めた以外は，重䈍な副作用は 1 例も認められなかつた。 副作用の男女別では男 9 例に対して女 18 例で女が倍数 であつた．麻酔の種別では浸潤麻酔のみのもの20 例， 伝達麻唒を併用したもの 7 例であつた。澧度别では $2 \%$ 3 例, 3\% 13 例, $4 \% 1$ 例で, 注射蜔は最少 $1.0 \mathrm{cc}$ り最高 $4.0 \mathrm{cc}$ 使用のものに忍められた。（丧 14 参照）

\section{総括およひ考按}

局所麻酔の具備すべき条件については從来出々上述べ

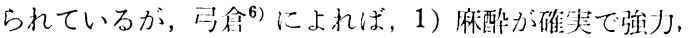

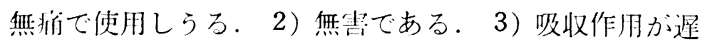
く吸収後分解が早く無刺激性に排泄される。大とがあけ られているが，現在その目的を 100\%满是させる属所麻 配剂はない。

Citanest は近時最も多く使用され，局所麻酔剂の効果， 副作用など比帜する上での基染となつている Xylocain の近表物啠であり，その効果については，才てに Åström ${ }^{4)}$, Persson ${ }^{5)}$, らによる秌物与駼, Eriksson ${ }^{7)}$, Gordn ${ }^{8)}$, Berling ${ }^{9)}$, Björn ${ }^{10)}$ らによる人体に刘与る我騟報告 に上り, 毒性はXylocain の 60\%であり, 麻酸力は同一 で，短洔間に麻酥効果が発現するなど述べられている。
Citanest の口腔外科臨床における使用成縝は, 本邦で

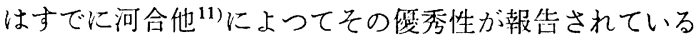
が，われわれの本剂使用成績においても，これらの報告 と同様に 320 例中の $92.1 \%$ に著效, 有効例が諗められ, 発現時間についても，2\%浸潤麻酔平均では 33 秒，3\% で 59 秒，4\%で 41 秒，伝達麻酔併用の平均では $2 \%$ で 3 分 0 秒, $3 \%$ で 2 分 42 秒といずれも迅速である.

麻酔持続時間は $2 \% ， 3 \%$ 浸㵎麻酔平均では約 68 分， 4\%では 44 分であり伝進麻酔併用の平均では 3\%で 117.4 分, $2 \%$ で 180分で, 持絖时間はやや知い感があ るが，これは Citanest の特珄によるものであり，一般 的な口腔外科的処罥は光分完了しらるものと思われる。

昖敬力は $2 \% ， 3 \% ， 4 \%$ 浸潤麻酔ではともに $100 \%$ 近い (十), (H) の数値を示し, 伝達麻酔併用の場合も 100\%の值を示し，その夏秀性がらかがわれる。

術中および術後の钼察においてては，手術時出血が $4 \%$ の場合やや多く見られたが，アドレナリンを含有しない ので当然の結果と思われる，後将詑については，全症例 の $15 \%$ 胎に軽度に見られた程度であり，㓣倾治㧧では， 治原後の钼察か十分に朋来ないため，正碓な数值をつか むことはもつかしいが，2例の不良を除いて，おおも拓 良奶であつた。

副作用については，全怔例を通じて西篗大副作用，開 口障舅などの特に配虙せねばならないような障吉は認め られず，わずか 27 例に柽度の副作用と思われるものが あつた。 
表 5. 注射液使用量と麻酔発現時间および持続時間（手術および保存）

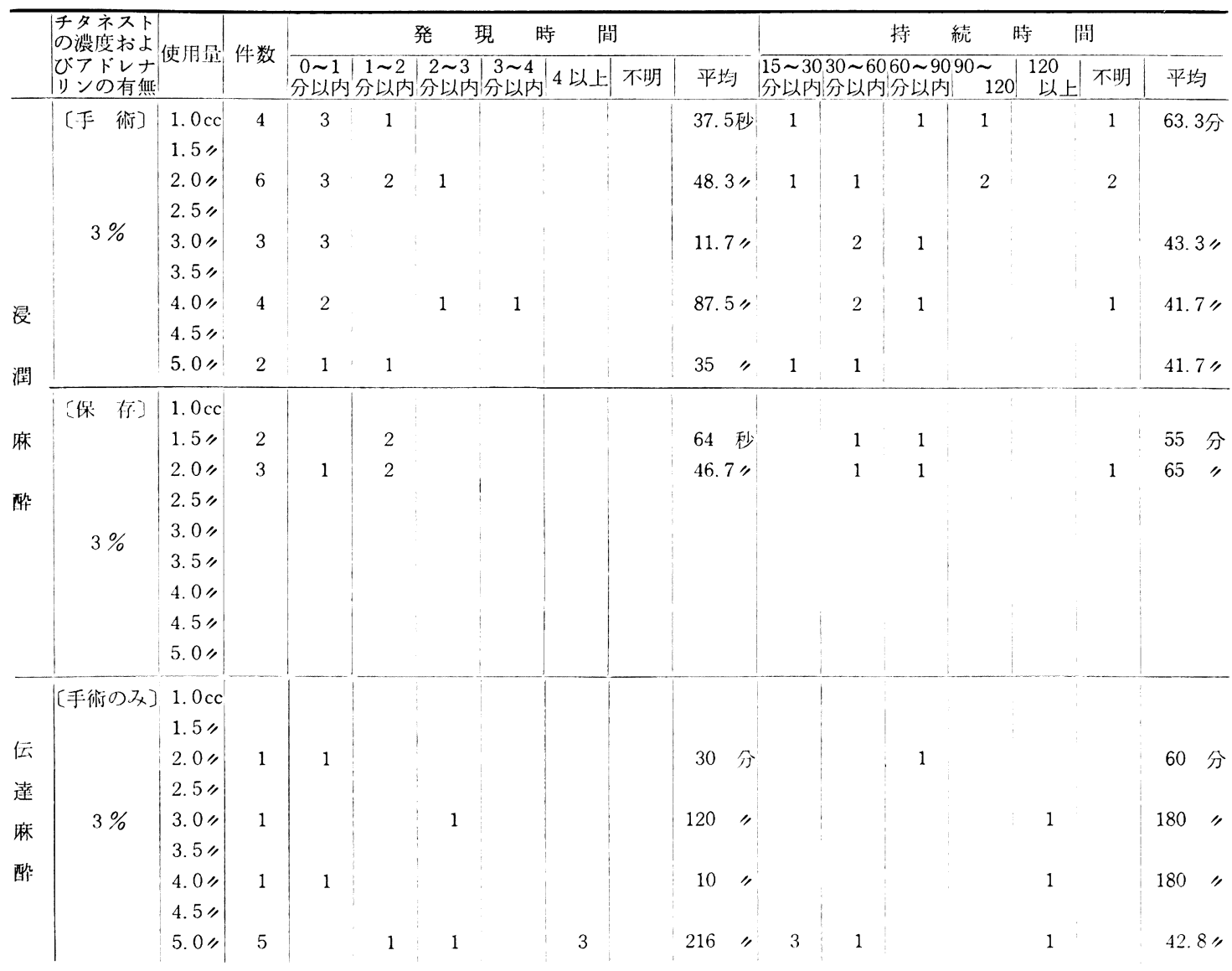

表 6. 抜歯の症例別平均麻酔発現および持繶時間

\begin{tabular}{|c|c|c|c|c|c|c|c|c|c|}
\hline 症例 & $\%$ & 件数 & 発現時間 & 持続時間 & 症例 & $\%$ & 件数 & 発現時間 & 持続時間 \\
\hline $\mathrm{C}_{4}$ & $\begin{array}{l}2 \\
3 \\
4 \\
\end{array}$ & $\begin{array}{l}27 \\
58 \\
27\end{array}$ & $\begin{array}{l}30.5 \text { 杪 } \\
66.0 " \\
41.0 "\end{array}$ & $\begin{array}{l}\text { 48分06秒 } \\
79 " \\
56 " 51 "\end{array}$ & $\begin{array}{l}\mathrm{C}_{3} \\
\text { 急化潘解炎 }\end{array}$ & $\begin{array}{l}2 \\
3 \\
4 \\
\end{array}$ & $\frac{-}{1}$ & $\begin{array}{c}- \\
180.0 " \\
-\end{array}$ & $\overline{40}$ \\
\hline $\begin{array}{c}\mathrm{C}_{4} \\
\text { 急化歯脱炎 }\end{array}$ & $\begin{array}{l}2 \\
3 \\
4 \\
\end{array}$ & $\overline{2}$ & $20.0 "$ & $25 \overline{-}$ & $\begin{array}{l}\mathrm{C}_{3} \\
\text { 橉䯣息肉 }\end{array}$ & $\begin{array}{l}2 \\
3 \\
4 \\
\end{array}$ & $\overline{1}$ & 180.0 & 300 \\
\hline $\begin{array}{c}\mathrm{C}_{3} \\
\text { 垔急性化腈性: } \\
\text { 骨膜炎 }\end{array}$ & $\begin{array}{l}2 \\
3 \\
4 \\
\end{array}$ & $\frac{-}{1}$ & $60.0 "$ & $180 \overline{-}$ & 転 位 歯 & $\begin{array}{l}2 \\
3 \\
4\end{array}$ & $\begin{array}{r}1 \\
2 \\
-\end{array}$ & $\begin{array}{l}10.0 " 1 \\
45.0 " \\
-\end{array}$ & $\begin{array}{l}35 \\
45 \\
-\end{array}$ \\
\hline $\begin{array}{l}\mathrm{C}_{3} \\
\text { 各種蜼管艀炎 }\end{array}$ & $\begin{array}{l}2 \\
3 \\
1\end{array}$ & $\begin{array}{l}1 \\
8 \\
1 \\
\end{array}$ & $\begin{array}{l}15.0 \\
92.0 " \\
-\end{array}$ & $\begin{array}{l}15 " \\
58 " \\
15 "\end{array}$ & 過 剩 橉 & $\begin{array}{l}2 \\
3 \\
4\end{array}$ & $\begin{array}{l}1 \\
1 \\
-\end{array}$ & $\begin{array}{l}10.0 " \\
120.0 " \\
-\end{array}$ & $\begin{array}{r}150 \\
60 \\
-\end{array}$ \\
\hline $\begin{array}{l}\mathrm{C}_{3} \\
\text { 急化继膜炎 }\end{array}$ & $\begin{array}{l}2 \\
3 \\
4\end{array}$ & 15 & $\begin{array}{l}10.0 \\
52.0 " \\
-\end{array}$ & $\begin{array}{l}50 " \\
70 " \\
\end{array}$ & 乳迷残存 & $\begin{array}{l}2 \\
3 \\
4 \\
\end{array}$ & $\frac{-}{1}$ & $\frac{\overline{-}}{60.0}$ & $\bar{z}$ \\
\hline $\begin{array}{c}\mathrm{C}_{3} \\
\text { 慢化粕膜炎 }\end{array}$ & $\begin{array}{l}2 \\
3 \\
4\end{array}$ & $\begin{array}{c}4 \\
33 \\
8\end{array}$ & $\begin{array}{l}56.5 " 1 \\
71.0 " \\
51.5 "\end{array}$ & $\begin{array}{l}76 " 1 \\
77 " \\
80 "\end{array}$ & 智阙周罒炎 & $\begin{array}{l}2 \\
3 \\
4 \\
\end{array}$ & $\overline{10}$ & $120.0 "$ & $\overline{147}$ 分15帕 \\
\hline $\begin{array}{c}\mathrm{C}_{3} \\
\text { 歯牙破折 }\end{array}$ & $\begin{array}{l}2 \\
3 \\
4\end{array}$ & $\begin{array}{l}1 \\
1 \\
3\end{array}$ & $\begin{array}{r}15.0 " \\
120.0 " \\
37.5 "\end{array}$ & $\begin{array}{l}60 " \\
15 " \\
17 " 30 "\end{array}$ & 完企埋伏䒜 & $\begin{array}{l}2 \\
3 \\
4\end{array}$ & $\overline{10}$ & $260.0 "$ & $\overline{118 " \prime}$ \\
\hline 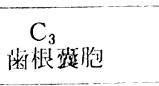 & $\begin{array}{l}2 \\
3 \\
4\end{array}$ & $\begin{array}{l}- \\
1 \\
1\end{array}$ & $\begin{array}{l}60.0 \text { " } \\
\text { 不 明 }\end{array}$ & $\begin{array}{r}100.0 " \\
30.0 "\end{array}$ & 不完全埋伏橉 & $\begin{array}{l}2 \\
3 \\
4\end{array}$ & $\frac{-}{4}$ & $54.0 "$ & $\overline{78} " 45$ \\
\hline $\mathrm{C}_{3}$ & $\begin{array}{l}2 \\
3 \\
4\end{array}$ & $\begin{array}{l}3 \\
18 \\
-\end{array}$ & $\begin{array}{c}42.5 " \\
81.5 " \\
-\quad "\end{array}$ & $\begin{array}{l}120 \\
112\end{array}$ & $P_{3}$ および $P_{4}$ & $\begin{array}{l}2 \\
3 \\
4\end{array}$ & $\begin{array}{c}8 \\
29 \\
5\end{array}$ & $\begin{array}{l}51.5 " \\
56.5 " \\
42.5 "\end{array}$ & $\begin{aligned} 100 & =24 \\
71 & =15 \\
40 & =30\end{aligned}$ \\
\hline
\end{tabular}


表 7. 手術の症例別平均麻枠発垷および持繞時間

\begin{tabular}{|c|c|c|c|c|c|}
\hline 症例 & 乎術法 & $\%$ & 件数 & 発現時閆 & 持続時間 \\
\hline 煩 部 微 澺 & 切開 & 3 & 1 & 20 秒 & 30 分 \\
\hline 歯槽简々 折 & 整形 & 3 & 1 & $120 "$ & $180 "$ \\
\hline 唾＼cjkstart石 & 摘出 & 3 & 1 & $5 "$ & $60 "$ \\
\hline エプーリス & 切除 & 3 & 1 & $30 "$ & $105 "$ \\
\hline $\mathrm{P}_{2} \sim \mathrm{P}_{3}$ & 切除 & 3 & 5 & $88 "$ & $45 "$ \\
\hline 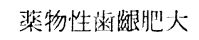 & 切除 & 3 & 1 & $30 "$ & $30 "$ \\
\hline 歯 根 程 胞 & 根切 & 3 & 4 & $70 "$ & 35 分55秒 \\
\hline 歯槽骨叫収不企 & 整形 & 3 & 7 & $51.5 "$ & $78.21 "$ \\
\hline 慢性湈槽，胃炎 & 搟爬 & 3 & 1 & $10 "$ & $180 "$ \\
\hline 亜急性化膿性肖炎 & 粪爬 & 3 & 1 & $10 "$ & $40 "$ \\
\hline $\begin{array}{l}\text { 慢性限局性䫑 } \\
\text { 炎 }\end{array}$ & 择爬 & 3 & 1 & $360 "$ & $120 "$ \\
\hline 抜幽窝感染 & 㭗爬 & 3 & 1 & $10 "$ & $50 "$ \\
\hline 上顎 获 胞 & 摘出 & 3 & 1 & $240 "$ & $25 "$ \\
\hline 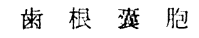 & 摘出 & 3 & 1 & $120 "$ & $4 "$ \\
\hline
\end{tabular}

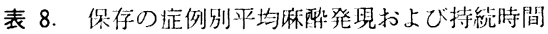

\begin{tabular}{|c|c|c|c|c|c|}
\hline 症例 & 術式 & $\%$ & 件数 & 発現時間 & 持続時間 \\
\hline $\mathrm{C}_{3}$ 急化㳜 & 拔成任 & 3 & 2 & 60 秒 & 70 分 \\
\hline $\mathrm{C}_{3}$ 洁塄性歯留炎 & 拔蹃 & 3 & 2 & $40 "$ & $50 "$ \\
\hline 知觉過敏症 & 形成 & 3 & 1 & $60 "$ & - \\
\hline
\end{tabular}

表 9. $2 \%$ Citanest 部位別平均発現および持続時間

\begin{tabular}{|c|c|c|c|c|}
\hline 部 位 & 歯数 & 件数 & 発現時間平均值 & 持続時間平均值 \\
\hline \multirow{4}{*}{$\begin{array}{l}\text { 上 颚 } \\
4 \text { 前㴹 }\end{array}$} & 1 & 5 & 15秒 & 85 分 \\
\hline & 2 & 2 & 65 & 82.5 \\
\hline & 3 & 0 & 0 & 0 \\
\hline & 4 & 0 & 0 & 0 \\
\hline \multirow[b]{2}{*}{ 下 哿 } & 1 & 2 & 75 & 87.5 \\
\hline & 2 & 0 & 0 & 0 \\
\hline \multirow[t]{2}{*}{4 前歯 } & 3 & 0 & 0 & 0 \\
\hline & 4 & 0 & 0 & 0 \\
\hline 上顎犬米 & 1 & 6 & 34.5 & 55 \\
\hline 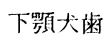 & 1 & 0 & 0 & 0 \\
\hline \multirow{4}{*}{$\begin{array}{l}\text { 上 䫇 } \\
\text { 白 棦 }\end{array}$} & 1 & 10 & 55 & 85 \\
\hline & 2 & 5 & 15 & 38.3 \\
\hline & 3 & 0 & 0 & 0 \\
\hline & 4 & 0 & 0 & 0 \\
\hline \multirow{2}{*}{ 下 颚 } & 1 & 6 & 26.7 & 39.2 \\
\hline & 2 & 1 & 120 & 40 \\
\hline \multirow[t]{2}{*}{ 日 将 } & 3 & 0 & 0 & 0 \\
\hline & 4 & 0 & 0 & 0 \\
\hline 上喕简踭 & 1 & 5 & 36 & 52.5 \\
\hline 下嚬智的 & 1 & 5 & 46 & 108.8 \\
\hline
\end{tabular}

表 10. 3\% Citanest 部位別平均発現および持絖脂間

\begin{tabular}{|c|c|c|c|c|}
\hline 部 位 & 咪数 & 件数 & 発現時間平均值 & 掉続時間平均值 \\
\hline \multirow{4}{*}{$\begin{array}{l}\text { 上 隫 } \\
4 \text { 解谜 }\end{array}$} & 1 & 16 & 71.3 秒 & 51.9 分 \\
\hline & 2 & 2 & 30 & 35 \\
\hline & 3 & 2 & 20 & 90 \\
\hline & 4 & 0 & 0 & 0 \\
\hline \multirow{4}{*}{$\begin{array}{l}\text { 下 買 } \\
4 \text { 欮歯 }\end{array}$} & 1 & 2 & 75 & 30 \\
\hline & 2 & 1 & 不明 & 15 \\
\hline & 3 & 0 & 0 & 0 \\
\hline & 4 & 0 & 0 & 0 \\
\hline 上靧犬歯 & 1 & 11 & 74.5 & 58.9 \\
\hline 下顎犬料 & 1 & 2 & 60 & 25 \\
\hline \multirow{4}{*}{ 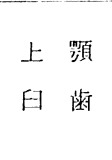 } & 1 & 35 & 48.9 & 70.9 \\
\hline & 2 & 8 & 70.6 & 130 \\
\hline & 3 & 2 & 90 & 40 \\
\hline & 4 & 1 & 30 & 20 \\
\hline \multirow[b]{2}{*}{ 下 顎 } & 1 & 44 & 72.4 & 78.7 \\
\hline & 2 & 5 & 48 & 50 \\
\hline \multirow[t]{2}{*}{ 臼眯 } & 3 & 3 & 64 & 120 \\
\hline & 4 & 0 & 0 & 0 \\
\hline 上罘智歯 & 1 & 24 & 69.1 & 76.8 \\
\hline 下䁶智歯 & 1 & 42 & 147. 2 & 129. 2 \\
\hline
\end{tabular}

表 11. $4 \%$ Citanest 部位別平均発現および持続時間

\begin{tabular}{|c|c|c|c|c|}
\hline 部 位 & 数数 & 件数 & 発現時間平均值 & 持続時間平均值 \\
\hline \multirow{4}{*}{$\begin{array}{l}\text { 上 顎 } \\
4 \text { 前歯 }\end{array}$} & 1 & 3 & 23. 3秒 & 45分 \\
\hline & 2 & 0 & 0 & 0 \\
\hline & 3 & 1 & 60 & 90 \\
\hline & 4 & 0 & 0 & 0 \\
\hline \multirow{4}{*}{$\begin{array}{l}\text { 下 频 } \\
4 \text { 前药 }\end{array}$} & 1 & 1 & 30 & 10 \\
\hline & 2 & 0 & 0 & 0 \\
\hline & 3 & 0 & 0 & 0 \\
\hline & 4 & 0 & 0 & 0 \\
\hline 上影犬貲 & 1 & 2 & 45 & 90 \\
\hline 下顋犬歯 & 1 & 1 & 30 & 30 \\
\hline \multirow{4}{*}{$\begin{array}{l}\text { 上頻 } \\
\text { 白 嵝 }\end{array}$} & 1 & 11 & 42.3 & 35.8 \\
\hline & 2 & 2 & 30 & 不明 \\
\hline & 3 & 3 & 40 & 36.7 \\
\hline & 4 & 0 & 0 & 0 \\
\hline \multirow{4}{*}{$\begin{array}{ll}\text { 下 } & \text { 喕 } \\
\text { 日 } & \text { 粲 }\end{array}$} & 1 & 13 & 52.7 & 32.1 \\
\hline & 2 & 2 & 30 & 46.5 \\
\hline & 3 & 0 & 0 & 0 \\
\hline & 4 & 0 & 0 & 0 \\
\hline 上買秚歯 & 1 & 0 & 0 & 0 \\
\hline 下䫑智歯 & 1 & 5 & 45 & 133.8 \\
\hline
\end{tabular}


表 12. 拡散力

\begin{tabular}{|c|c|c|c|c|c|c|c|c|c|c|c|}
\hline 麻晓別 & $\begin{array}{l}\text { Citanest の濃度および } \\
\text { アドレナリソ }\end{array}$ & 性 別 & 件 数 & \pm & $\%$ & + & $\%$ & $H$ & $\%$ & 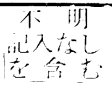 & $\%$ \\
\hline \multirow{3}{*}{ 浸 } & \multirow{3}{*}{$\begin{array}{c}2 \% \\
\text { アドレナリン } \\
1: 200,000\end{array}$} & 男 & 23 & 0 & & 20 & 86.9 & 3 & 13.0 & 0 & \\
\hline & & 女 & 23 & 0 & I & 23 & 100 & 0 & - & 0 & / \\
\hline & & 訣 & 46 & 0 & & 43 & 93.4 & 3 & 6.5 & 0 & \\
\hline 㴸 & \multirow{3}{*}{$\begin{array}{c}3 \% \\
\text { アドレナリン } \\
1: 300,000\end{array}$} & 男 & 73 & 3 & 4. 2 & 67 & 91.7 & 2 & 2.7 & 1 & 1. 4 \\
\hline \multirow{2}{*}{ 路 } & & 久久 & 106 & 2 & 1.9 & 98 & 92.4 & 1 & 3.8 & 2 & 1.9 \\
\hline & & 棓 & 179 & 5 & 2.8 & 165 & 92.1 & 6 & 3.3 & 3 & 1. 7 \\
\hline \multirow[t]{3}{*}{ 酭 } & \multirow{3}{*}{$\begin{array}{c}4 \% \\
\text { アドレナリン含有せず }\end{array}$} & 男 & 22 & 0 & - & 21 & 95.4 & 0 & & 1 & 4.5 \\
\hline & & 女 & 24 & 1 & 4. 2 & 23 & 95.8 & 0 & I & 0 & - \\
\hline & & 計 & 46 & 1 & 2.2 & 44 & 95.6 & 0 & & 1 & 2. 2 \\
\hline \multirow{3}{*}{ 伝 } & \multirow{3}{*}{$\begin{array}{c}\text { アドレナリン } \\
1: 200,000\end{array}$} & 男 & 0 & 0 & & 0 & - & 0 & & 0 & \\
\hline & & 女 & 1 & 0 & / & 1 & $1 \mathrm{CO}$ & 0 & I & 0 & I \\
\hline & & 計 & 1 & 0 & & 1 & 100 & 0 & & 0 & \\
\hline 莘 & \multirow{3}{*}{$\begin{array}{c}3 \% \\
\text { アトレナリン } \\
1: 300.000\end{array}$} & 男 & 19 & 0 & & 16 & 84.2 & 3 & 15.7 & 0 & \\
\hline \multirow{2}{*}{ 糜 } & & 女 & 29 & 0 & I & 26 & 89.6 & 3 & 10.3 & 0 & I \\
\hline & & 計 & 48 & 0 & & 42 & 87.5 & 6 & 12.5 & 0 & \\
\hline \multirow[t]{3}{*}{ 醋 } & \multirow{3}{*}{$\begin{array}{c}4 \% \\
\text { アドレナリン含有せず }\end{array}$} & 男 & 0 & 0 & & 0 & 0 & 0 & & 0 & \\
\hline & & 文 & 0 & 0 & I & 0 & 0 & 0 & I & 0 & I \\
\hline & & 計 & 0 & 0 & & 0 & 0 & 0 & & 0 & \\
\hline
\end{tabular}

表 13. 術中扰よび術後の钼察

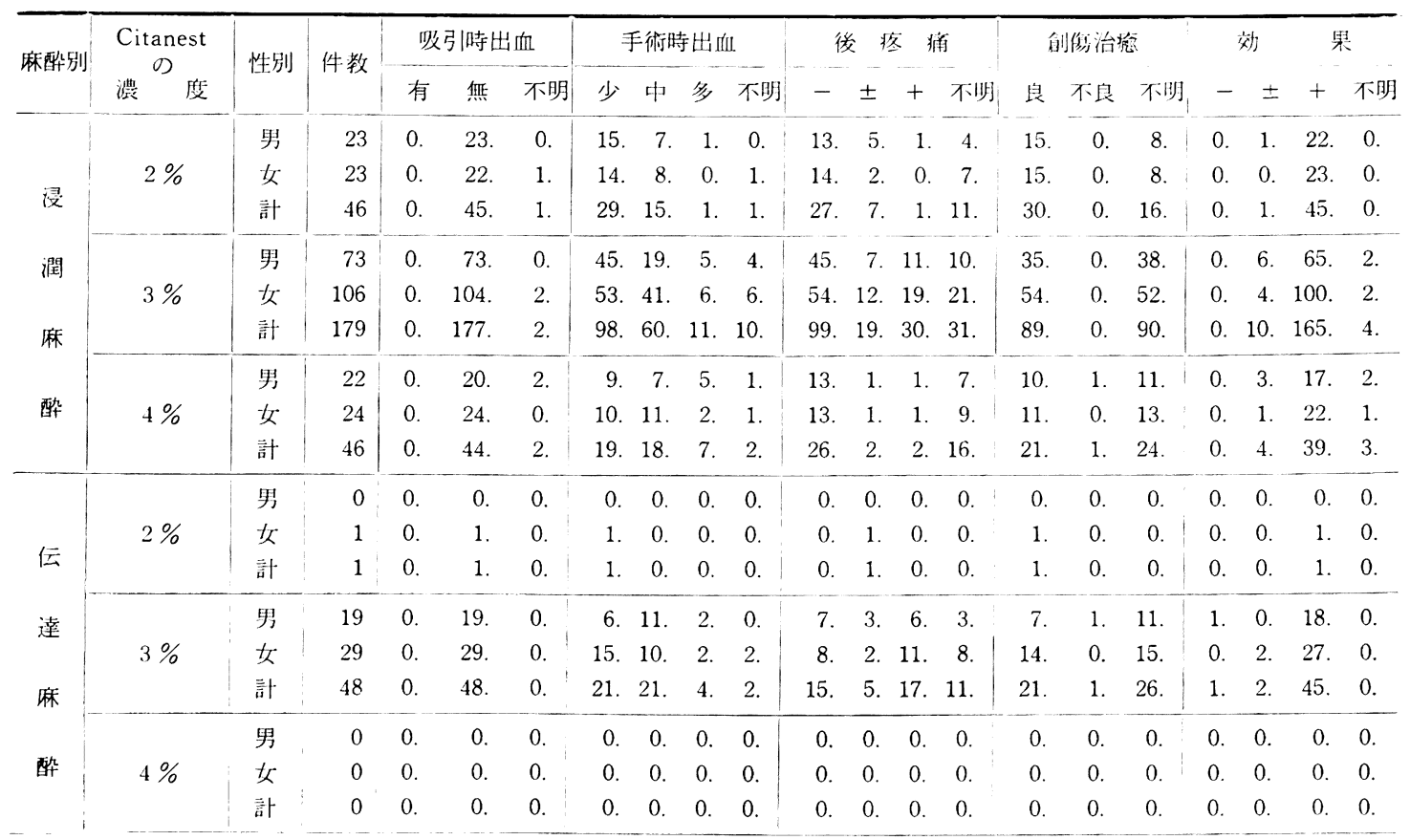

（注）不明は記入のなかったものも含吉。 
表 14. 副

用

\begin{tabular}{|c|c|c|c|c|c|c|c|c|c|c|c|c|c|c|c|c|c|c|c|c|c|}
\hline \multirow[b]{2}{*}{ 年令 } & \multirow{2}{*}{ 性别 } & \multirow{2}{*}{ 病 } & \multirow[b]{2}{*}{ 名 } & \multirow{2}{*}{ 手術名 } & \multirow{2}{*}{ 麻形别 } & \multirow{2}{*}{\multicolumn{2}{|c|}{\begin{tabular}{|l|} 
チタネスト \\
の濃度およ \\
びアトレナ \\
リソ有無
\end{tabular}}} & \multirow[b]{2}{*}{ 诖射星 } & \multirow{2}{*}{ 発現 } & \multirow{2}{*}{$\begin{array}{l}\text { 持続 } \\
\text { 時間 }\end{array}$} & \multicolumn{3}{|c|}{$\begin{array}{l}\text { Premedi- } \\
\text { 手術所 cation } の\end{array}$} & \multirow{2}{*}{$\begin{array}{l}\text { 択散 } \\
\text { 力 }\end{array}$} & \multirow{2}{*}{$\begin{array}{l}\text { 吸引 } \\
\text { 時出 } \\
\text { IIII }\end{array}$} & \multirow{2}{*}{\multicolumn{2}{|c|}{$\begin{array}{l}\text { 㓱㴬後疼 } \\
\text { 治诚痛 }\end{array}$}} & \multirow{2}{*}{\multicolumn{2}{|c|}{ 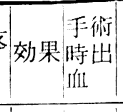 }} & \multirow{2}{*}{\multicolumn{2}{|c|}{ 副作用 }} \\
\hline & & & & & & & & & & & 要時間 & 有 & 無 & & & & & & & & \\
\hline 29 & $\delta$ & 8 & $\mathrm{C}_{4}$ & 㧡歯 & 漫麻 & $2 \%$ & 有 & $1.5 \mathrm{cc}$ & 30秒 & 30分 & 5分 & & 0 & + & ナシ & 良 & + & + & 中 & & \\
\hline 50 & $q$ & 67 & $\mathrm{C}_{4}$ & ;" & $"$ & " & $"$ & $2 "$ & $10 "$ & 不明 & $2 "$ & & 0 & + & " & ব & - & + & 小 & 頭 & \\
\hline 34 & q & 13 & $\mathrm{C}_{4}$ & " & " & " & $"$ & $2 "$ & $30=$ & 30 分 & $1 " \prime$ & & 0 & + & " & 良 & - & + & 小 & 頭 & 痛 \\
\hline 55 & $\delta$ & 65 & 急化 Per $C_{4}$ & " & " & $3 \%$ & " & $2.7 "$ & $10 "$ & $30 "$ & $25 "$ & & 0 & + & " & 良 & - & + & 小 & 貧 & Inl \\
\hline 26 & $\hat{o}$ & 17 & 慢化 Per $C_{3}$ & " & $"$ & " & " & $1.8 \%$ & $10 "$ & $30 "$ & $5 "$ & & 0 & + & " & l & + & + & 小 & 頭部ふ & 50 \\
\hline 35 & $\hat{\delta}$ & & 僈化 $\mathrm{Per} \mathrm{C}_{3}$ & " & 滠伝森 & " & " & $2.7 "$ & $180 "$ & $110 "$ & ノ & & 0 & - & " & I & - & - & 中 & 熱 & 感 \\
\hline 24 & $\hat{o}$ & 18 & 急化 $\mathrm{Pul} \mathrm{C}_{3}$ & " & 渭麻 & " & $"$ & $1.8 "$ & $180 "$ & $40 "$ & $10 "$ & & 0 & + & " & ノ & - & + & 小 & 檼 & 心 \\
\hline 28 & $\hat{o}$ & $1 \overline{8}$ & 歯骮息肉 $\mathrm{C}_{3}$ & " & 添伝咻 & " & $"$ & $4 "$ & $180 "$ & $300 "$ & $5 "$ & & 0 & + & " & 良 & + & + & 中 & 頭 & \\
\hline 46 & $\delta$ & 876 & $5 \quad P_{3}$ & " & " & " & $"$ & & $30=$ & $120 "$ & $2 "$ & & 0 & + & $"$ & I & - & + & 中 & 発 & \\
\hline 43 & $\hat{o}$ & 65 & 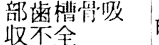 & 幽慒整形 & 浸厤 & " & $"$ & $1 "$ & $30 "$ & 不明 & $15 "$ & & 0 & + & " & l & - & + & 小 & 頭 & 痛 \\
\hline 42 & 9 & 17 & $\mathrm{C}_{4}$ & 拻蔽 & " & " & $"$ & $1.8 \%$ & $30 "$ & $180 "$ & $2 "$ & & 0 & + & $"$ & 良 & - & + & 大 & 頭 & 痛 \\
\hline 47 & $q$ & 8 & $\mathrm{C}_{4}$ & " & 侵妘麻 & " & " & $2 "$ & $120 "$ & $150 "$ & $5 "$ & & 0 & + & $"$ & 良 & \pm & + & 中 & 術後 & 钱熱 \\
\hline 20 & 운 & 18 & 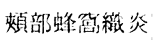 & " & " & " & " & & $300 "$ & $130 "$ & $10 "$ & & 0 & + & $"$ & 良 & - & + & 中 & 食欲 & 不振 \\
\hline 30 & $q$ & 17 & 急化 Per $C_{3}$ & " & 浸麻 & " & " & $1.8 "$ & $10 "$ & 不明 & $5 "$ & & 0 & + & " & / & / & + & 中 & 頭 & \\
\hline 31 & q & 6 & 急化 Per $C_{3}$ & " & " & " & " & $0.9 "$ & $60 "$ & $32 "$ & $15 "$ & & 0 & + & " & 良 & - & + & 小 & 睡 & 気 \\
\hline 21 & $q$ & & 急化 Per $\mathrm{C}_{3}$ & " & " & " & " & $2 "$ & $120 "$ & $60 "$ & $5 "$ & & 0 & + & " & 良 & - & + & & 頭 & 痛 \\
\hline 23 & q & 17 & 慢化 Per $C_{3}$ & " & 湜伝嫲 & " & " & $2.4 "$ & $180 "$ & $180 "$ & $10 "$ & & 0 & H & " & 良 & + & + & 中 & 盆 & 血 \\
\hline 35 & $q$ & 81 & 慢化 Per $C_{3}$ & " & 浸麻 & " & " & $1.5 \%$ & $30 "$ & $30 " 1$ & $5 "$ & & 0 & + & $"$ & 良 & - & + & 中 & 頭 & \\
\hline 57 & q & $\sqrt{4}$ & 侵化 Per $\mathrm{C}_{3}$ & " & " & " & $"$ & $2 \geqslant$ & $120 "$ & $40 "$ & $1 " \prime$ & & 0 & + & $"$ & 良 & - & + & 小 & 頭 & 瘺 \\
\hline 23 & q & $1 \overline{8}$ & 悡齿周畍炎 & " & 伩伝跦 & " & " & $2.4 "$ & $180 "$ & $180 "$ & $10 "$ & & 0 & $H$ & $"$ & 良 & + & + & 中 & 貧 & Ifll \\
\hline 57 & 웅 & 18 & 智占周用炎 & " & 浸麻 & " & " & $1.8 "$ & $30 "$ & $60 " 1$ & $4 "$ & & 0 & + & " & 良 & \pm & + & 中 & 頭 & 捔 \\
\hline 47 & 우 & 21 & $\mathrm{P}_{4}$ & " & " & " & " & $0.9 "$ & $30 "$ & $150 "$ & $1 " \prime$ & & 0 & + & " & 良 & - & + & 中 & 僚急 & 急感 \\
\hline 51 & $q$ & 17 & $\mathrm{P}_{4}$ & " & " & " & " & $1.8 "$ & $30 "$ & $120 "$ & $0.3 "$ & & 0 & + & " & 良 & - & + & 中心 & 有こ & $=\eta$ \\
\hline 56 & \% & 211 & $\mathrm{P}_{4}$ & " & " & " & " & $1 "$ & $120 "$ & 不明 & $3 "$ & & 0 & + & " & / & I & + & 中 & 頭 & 痛 \\
\hline 13 & $q$ & & 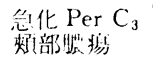 & 媕 & " & " & " & $2.7 "$ & $20 "$ & 30分 & " & & 0 & + & " & 良 & - & + & 中 & 貣 & Iflin \\
\hline 21 & 우 & 313 & $\mathrm{P}_{2}$ & 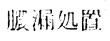 & " & " & " & $4=$ & $180 "$ & $35 "$ & $30 "$ & & 0 & + & " & 良 & + & + & 多 & 頭 & 痛 \\
\hline 63 & $\hat{o}$ & $i \overline{34}$ & $\mathrm{C}_{4}$ & 拔粰 & " & $.1 \%$ & 無 & $2 "$ & $30 "$ & $30 "$ & $0.5 "$ & & 0 & + & " & 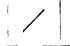 & \pm & + & 中 & 頭 & 痛 \\
\hline
\end{tabular}

（借考）斜線は記入のないうの.

\section{結語}

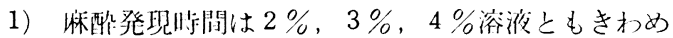
て迅速で, Citanestの組織内への湜透性が優れているこ とを示すものと考えられる。

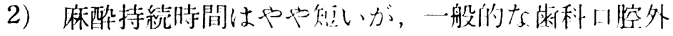
科的処置を充分に完了し得る持続性を示した。

3）昖敬拟良好である。

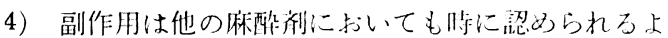
らなものを除いては，特に配麀すべきものはない

5）アドレナリンを含有しない $4 \%$ Citanest 漁液で は，術中の出血显がやや多い場合が浔められた。

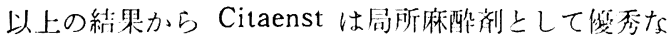
ものと考えられる.

\section{文献}

1) Einhorn: 6) 上り引用

2) Löfgren : 12) より引用

3) Tegner : 12) より引用
4) Aström : Some pharmacological properties of o-methyl- $\alpha$-propylaminopropionamide, a new local anaesthetic, Brit, J. Pharmacol. 32 44, 1961.

5) Persson: The Toxicity of some local anesthetics after application on different mucous membrancs and its relation to anesthetic action on the nasal mucosa of the rabbit. Survey of Anesthesiology, 6, 327 328. 1962.

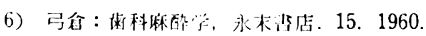

7) Ericsson : L-67 Experimental eratuation of a new local anaesthetic in man. Acta anaesth. Scandinav., 5, 191 205, 1961.

8) Gordn : Clinical trials of a new local anaesthetis, Acta anaesth. Scandinav. Supplementum, II, 81 85, 1959.

9), 10) Berling and Björn : L-67 A new local anesthetic of anilide type. Experimental determination of its efficacy in dental plexus anesthesia in man, in preparation. Sv. Tandl. fürb. itidn 52. 511. 1960.

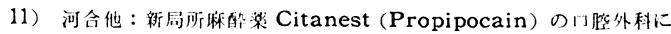

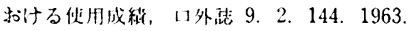

12) Wiedling:Studies on $\alpha$-n-propylamino-2-methyl-propionanilide. a new local anaesthetic. pActa harmacol et Toxicol, 17, 233 244, 1960. 